\title{
Myo-inositol Catabolism in Salmonella typhimurium: Enzyme Repression Dependent on Growth History of Organism
}

\author{
By T. K. SUNDARAM \\ Department of Biochemistry, School of Biological Sciences, \\ University of Leicester, Leicester
}

(Received 9 May 1972)

\begin{abstract}
SUMMARY
Biochemical and genetic evidence suggests that NADPH-dependent 2-keto$m y o$-inositol reductase and 2-keto-myo-inositol dehydratase are associated with myo-inositol catabolism in Salmonella typhimurium. When growth of this organism is initiated in salts medium containing citrate and inositol using a citrate-grown inoculum, ketoinositol reductase is virtually completely repressed. By contrast, when inositol-grown organisms are used as inoculum, a relatively high level of the enzyme is present in bacteria even after a 20 -fold increase in mass in the citrate + inositol medium. Under these conditions, inositol is used for growth to a significant extent, and citrate is utilized to a lesser extent than when growth is started with citrate-grown organisms. Thus by varying the growth history of the organism, different biochemical phenotypes can be produced without any change in the genotype or in the immediate environmental conditions.
\end{abstract}

\section{INTRODUCTION}

The catabolism of myo-inositol in Aerobacter aerogenes starts with the formation of 2-keto-myo-inositol in a $\mathrm{NAD}^{+}$-linked dehydrogenation. The ketoinositol then undergoes dehydration; further stepwise degradation eventually results in the production of glycolytic intermediates (Berman \& Magasanik, 1966a,b; Anderson \& Magasanik, I971 $a, b$ ). This pathway is different from the one which operates in yeast, plants and rat tissue and which entails the reaction of inositol with molecular oxygen leading to the cleavage of the cyclohexane ring and the formation of D-glucuronic acid (Charalampous, I959; Sivak \& HoffmanOstenhof, 196I; Loewus, Kelley \& Neufeld, 1962). Like A. aerogenes, Salmonella typhimurium LT2, which bears a close taxonomic relationship to it, is capable of growing on myo-inositol as the sole source of carbon. Inositol degradation in Salmonella typhimurium was deemed worth investigating, since this organism, in contrast to $A$. aerogenes, has a well-studied genetic system that easily lends itself to experimentation. This paper presents a study of the early enzymes of this catabolic pathway in S. typhimurium and of the repression of this enzyme system by citrate; the degree of repression varied with the growth history of the organism.

\section{METHODS}

Organisms and culture conditions. Salmonella typhimurium LT2 and the mutants derived from it in this study were grown on the following salts medium, supplemented with the desired compounds as carbon source: $\mathrm{K}_{2} \mathrm{HPO}_{4}, 10.5 \mathrm{~g} ; \mathrm{KH}_{2} \mathrm{PO}_{4}, 4.5 \mathrm{~g}$; sodium $\left(\mathrm{Na}_{3}\right)$ citrate. $2 \mathrm{H}_{2} \mathrm{O}, 0 . \mathrm{I} 5 \mathrm{~g} ; \mathrm{MgSO}_{4} .7 \mathrm{H}_{2} \mathrm{O}$, O.I g; $\left(\mathrm{NH}_{4}\right)_{2} \mathrm{SO}_{4}$, I g; and distilled water to $\mathrm{I} \mathrm{l}$. Compounds to be used as carbon sources were sterilized separately and aseptically added 
to the salts medium. Cultures were incubated with shaking, usually in a gyratory water-bath shaker (New Brunswick Scientific Company, New Brunswick, New Jersey, U.S.A.) maintained at $37^{\circ} \mathrm{C}$. Growth was monitored by measuring turbidity as extinction at $620 \mathrm{~nm}$ in cuvettes of I cm light path using a Carl Zeiss spectrophotometer model PM QI I.

Acetobacter suboxydans $62 \mathrm{I}$, used in the preparation of 2-keto-myo-inositol from myoinositol, was obtained from the American Type Culture Collection, Washington, D.C. (ATCC 62I).

Aerobacter aerogenes 35, used in the enzymatic assay of myo-inositol in reaction mixtures, was grown as described by Berman \& Magasanik (I966a).

Chemicals. Myo-inositol, and the nicotinamide adenine nucleotides (NAD ${ }^{+}$and $\mathrm{NADP}^{+}$) and their reduced forms were obtained from Mann Research Laboratories, New York, N.Y., U.S.A., 2,3,5-triphenyltetrazolium chloride from Dajac Laboratories, Philadelphia, Pennsylvania, U.S.A., and $\left[\mathrm{I}, 5^{-14} \mathrm{C}\right]$ citrate of specific radioactivity $5 \cdot 32 \mathrm{mCi} / \mathrm{mmol}$ from New England Nuclear Corporation, Boston, Massachusetts, U.S.A. Chloramphenicol was a gift from Fugisawa Pharmaceutical Company, Osaka, Japan. 2-Keto-myo-inositol was prepared by the method of Posternak (1952). All other chemicals were readily available commercially and were of the highest purity offered.

Preparation of cell-free extracts. Organisms, after being harvested by centrifugation at $4{ }^{\circ} \mathrm{C}$ and washed with $0.85 \%(\mathrm{w} / \mathrm{v}) \mathrm{NaCl}$, were suspended in buffer (usually $20 \mathrm{~mm}$-potassium phosphate, $\mathrm{pH}_{7}$ ) and disrupted either in a Io $\mathrm{KHz}$ magnetostrictive oscillator (Raytheon) or in a MSE sonic disintegrator (Instrumentation Associates, New York, N.Y., U.S.A.). The cell homogenate thus obtained was centrifuged at $25000 \mathrm{~g}$ and $4{ }^{\circ} \mathrm{C}$ for $30 \mathrm{~min}$ and the supernatant liquid (cell-free extract) was collected.

Enzyme assays. Ketoinositol reductase was assayed in the following system ( $\mathrm{I} \mathrm{ml}$ ): potassium phosphate ( $\mathrm{pH} 7$ ), $50 \mu \mathrm{mol}$; NADPH, $0.15 \mu \mathrm{mol} ; 2$-keto-myo-inositol, $0.5 \mu \mathrm{mol}$; and cell extract. The rate of the enzyme reaction, which was initiated by the addition of ketoinositol, was measured at $25^{\circ} \mathrm{C}$ in terms of the decrease in extinction at $340 \mathrm{~nm}$ due to the oxidation of NADPH. One unit of enzyme caused a decrease in extinction of $0 . \mathrm{I}$ per min under these conditions.

Ketoinositol dehydratase was assayed as described by Berman \& Magasanik (I966a) by measuring the rate of increase in extinction at $260 \mathrm{~nm}$ in a system containing enzyme and 2-keto-myo-inositol at $\mathrm{pH} 6$. One unit of enzyme caused an increase in extinction of $0 \cdot \mathrm{I}$ per min under these conditions.

Protein in extracts was determined by the method of Lowry, Rosebrough, Farr \& Randall (I95I).

Incorporation of radioactivity from $\left[\mathrm{I}, 5^{-14} \mathrm{C}\right]$ citrate into trichloroacetic acid-insoluble material during growth. Samples ( $\mathrm{I} \mathrm{ml}$ ) of culture, withdrawn at appropriate times, were mixed with $0.4 \mathrm{ml}$ of $20 \%(\mathrm{w} / \mathrm{v})$ trichloroacetic acid. After standing in ice for at least $30 \mathrm{~min}$, the precipitates were collected on membrane filters $(24 \mathrm{~mm}$; Millipore Corporation, Massachusetts, U.S.A.) and washed with ice-cold $5 \%(\mathrm{w} / \mathrm{v})$ trichloroacetic acid. The filters with their precipitates were glued on to aluminium planchettes and dried, and the radioactivity was measured with a thin window gas flow counter (Nuclear Chicago Corporation, Des Plaines, Illinois, U.S.A.).

Determination of radioactivity remaining in the culture medium. Samples of culture, withdrawn at suitable times, were centrifuged at $4{ }^{\circ} \mathrm{C}$. The supernatant fluids were diluted fivefold with $0.02 \mathrm{~N}-\mathrm{HCl}$. Portions $(0 . \mathrm{I} \mathrm{ml})$ of the diluted samples were dried on aluminium planchettes, and the radioactivity was measured as described above. Since all the samples were treated in the same way, no correction was applied for self-absorption. 
Determination of myo-inositol. Myo-inositol in reaction mixtures was determined by the enzymatic method of Weissbach (I958).

$\left[1,5^{-14} \mathrm{C}\right]$ Citrate metabolism by non-growing organisms. Organisms from growing cultures were collected by centrifugation at $4{ }^{\circ} \mathrm{C}$ for $\mathrm{I} 5 \mathrm{~min}$ at $\mathrm{I} 5000 \mathrm{~g}$ and washed with salts medium. Suspensions of the organisms were prepared in this same medium. To each suspension $(5 \mathrm{ml})$ was added $0.3 \mathrm{ml}$ of a solution of chloramphenicol $(\mathrm{I} \mathrm{mg} / \mathrm{ml})$. The mixture was incubated with shaking at $36^{\circ} \mathrm{C}$ for $5 \mathrm{~min} ; 0.2 \mathrm{ml}$ of $\left[\mathrm{I}, 5^{-14} \mathrm{C}\right]$ citrate $(0.33 \mu \mathrm{Ci}, 0.06 \mu \mathrm{mol})$ was then added (zero time) and incubation was continued. Samples were withdrawn at suitable times and the organisms were immediately removed by membrane filtration. The filtrates were diluted fivefold with $0.02 \mathrm{~N}-\mathrm{HCl}$ and the radioactivity in $0 . \mathrm{I} \mathrm{ml}$ portions of the diluted filtrates was determined as described above.

Transduction. Lysates of the transducing phage $\mathrm{P}_{22}$ on wild-type Salmonella typhimurium and on mutants $\mathrm{D}$ and $\mathrm{I}$ were prepared and assayed for phage particles by standard procedures (Margolin, 1963). For transduction, $0.5 \mathrm{ml}$ of a suspension containing approximately $10^{9}$ cells of the recipient (mutant $\mathrm{I}$ ) strain was mixed with $0.5 \mathrm{ml}$ of phage lysate (diluted in the adsorption medium of Hershey \& Chase (1952) ) containing approximately $10^{10}$ phage particles grown on the donor (wild-type or mutant $\mathrm{D}$ ) strain. The mixture was incubated at $37^{\circ} \mathrm{C}$ for $\mathrm{Io} \mathrm{min}$, and $\mathrm{o} . \mathrm{I} \mathrm{ml}$ portions were spread on agar plates prepared from salts medium containing $0 \cdot 2 \%(\mathrm{w} / \mathrm{v})$ myo-inositol and $100 \mathrm{mg}$ of nutrient broth (Difco) per litre. The following two controls were also set up: (i) $0.5 \mathrm{ml}$ of recipient bacterial suspension was mixed with $0.5 \mathrm{ml}$ of adsorption medium and, after incubation at $37^{\circ} \mathrm{C}$ for Io min, $\mathrm{O} . \mathrm{I} \mathrm{ml}$ portions were plated as above - this was a check for spontaneous reversion of mutant $\mathrm{I}$ to wild-type; (ii) $0.5 \mathrm{ml}$ of recipient bacterial suspension was mixed with $0.5 \mathrm{ml}$ of a lysate in adsorption medium containing approximately $\mathrm{IO}^{10}$ particles of phage grown on mutant $\mathrm{I}$ and, after incubation at $37^{\circ} \mathrm{C}$ for $\mathrm{I} 0 \mathrm{~min}, 0.1 \mathrm{ml}$ portions were plated - this was a check for recombination due to unequal crossing-over between homologous chromosomes contributed by mutant I. All the plates were incubated at $37^{\circ} \mathrm{C}$ for 48 to $72 \mathrm{~h}$.

\section{RESULTS}

Degradation of myo-inositol by resting cells and in cell-free extracts. As shown in Fig. I, a washed suspension of Salmonella typhimurium grown on salts medium containing inositol as carbon source, readily oxidized inositol, consuming oxygen and liberating carbon dioxide in approximately equal amounts. The relatively low rate and extent of oxygen consumption and carbon dioxide production suggest that oxidation of substrate was incomplete, presumably due to assimilation and/or accumulation of catabolic products. Degradation of inositol occurred even under anaerobic conditions. In this experiment organisms (approximately $20 \mathrm{mg}$ dry weight) were incubated with $10 \mu \mathrm{mol}$ inositol in a Thunberg tube at $37^{\circ} \mathrm{C}$ for $3 \mathrm{~h}$. Anaerobic conditions were established in the tube by evacuating with a water pump, filling the tube with nitrogen gas and re-evacuating; the flushing with nitrogen and evacuation were twice repeated. Assay of residual inositol by the enzymatic method of Weissbach (1958) showed that at least $97 \%$ had been degraded. These findings suggested that myo-inositol was broken down in $S$. typhimurium via 2-keto-myo-inositol by a pathway similar to that operating in Aerobacter aerogenes (Anderson \& Magasanik, I97 I $a, b$; Berman \& Magasanik, $1966 a, b)$ rather than by direct cleavage of the ring structure of the cyclitol by oxygen producing D-glucuronic acid as in yeast and other organisms (Charalampous, 1959; Sivak \& Hoffman-Ostenhof, I96I; Loewus et al. 1962). This possibility was strengthened by the finding that an extract of inositol-grown $S$. typhimurium did not reduce D-glucuronic acid 


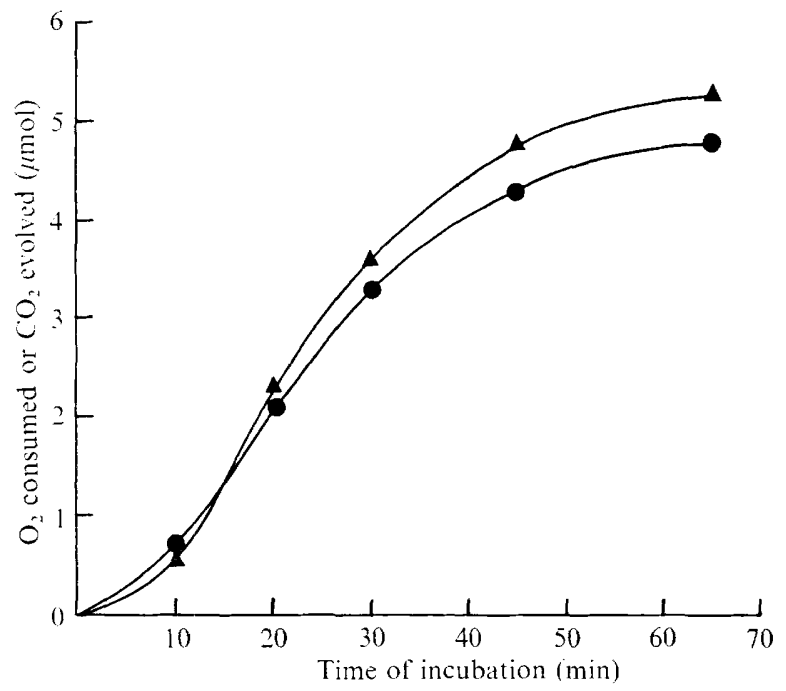

Fig. I. Oxidation of myo-inositol by resting cells of Salmonella typhimurium. Oxygen uptake (O) and carbon dioxide evolution $(\boldsymbol{\Delta})$ were measured at $37^{\circ} \mathrm{C}$ by the Warburg manometric method (Umbreit, Burris \& Stauffer, 1964) with air as gas phase. The complete reaction mixture contained

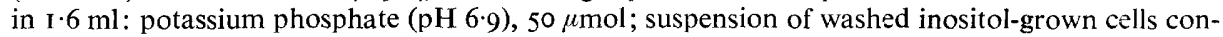
taining approximately $16 \mathrm{mg}$ dry wt of cells; and myo-inositol, $4 \mu \mathrm{mol}$.

\section{Table I. Formation of reducing material from myo-inositol by cell-free extract of Salmonella typhimurium}

Complete system contained in a total volume of $\mathrm{I} \mathrm{ml}$ : tris- $\mathrm{HCl}(\mathrm{pH} 7 \cdot 4)$, I $50 \mu \mathrm{mol}$; $\mathrm{NADP}^{+}$, I $\mu \mathrm{mol} ; m y o$-inositol, $10 \mu \mathrm{mol}$; and a dialysed cell-free extract of inositol-grown cells (containing approximately $3 \mathrm{mg}$ protein). Additions and omissions were made as indicated. After incubation at $37^{\circ} \mathrm{C}$ for $2 \mathrm{~h}$ with gentle shaking, $0.04 \mathrm{ml}$ of $50 \%(\mathrm{w} / \mathrm{v})$ trichloroacetic acid was added and the mixture centrifuged. To a portion $(0.7 \mathrm{ml})$ of the supernatant were added $0.1 \mathrm{ml}$ of $0.6 \%(\mathrm{w} / \mathrm{v})$ triphenyltetrazolium chloride and $0.1 \mathrm{ml}$ of $4 \mathrm{~N}-\mathrm{NaOH}$. After standing at room temperature for $30 \mathrm{~min}, 0 . \mathrm{I} \mathrm{ml}$ of $4 \mathrm{~N}$-acetic acid was added, followed by $2 \mathrm{ml}$ of $n$-propanol. The red colour produced by the reduction of the tetrazolium was read at $485 \mathrm{~nm}$ against a blank prepared from a similar reaction mixture which did not contain inositol.

$\begin{array}{lc}\text { System } & \text { Extinction at } 485 \mathrm{~nm} \\ \text { Complete } & 2.8 \\ \text { NADP omitted } & 0.02 \\ \text { NADP }^{+} \text {omitted, I } \mu \text { mol NAD }{ }^{+} \text {added } & 0 . \mathrm{II}^{\mathrm{I}}\end{array}$

in the presence of NADH or NADPH but did possess an enzyme that catalysed a reaction similar to the dehydration of 2-keto-myo-inositol occurring in $A$. aerogenes, as shown by the increase in extinction at $260 \mathrm{~nm}$ when the extract was incubated with 2-keto-myo-inositol. Yet no myo-inositol-dependent reduction of $\mathrm{NAD}^{+}$was obtained. Similar negative results were obtained when NADP ${ }^{+}$or an artificial electron acceptor such as 2,6-dichlorophenolindophenol was substituted for $\mathrm{NAD}^{+}$. However, other findings, summarized below, appear to support the idea that the pathways of inositol dissimilation in S. typhimurium and in A. aerogenes are similar. Thus an extract of inositol-grown $S$. typhimurium catalysed a rapid oxidation of NADPH (NADH was much less effective) in the presence of 2-keto-myoinositol, a reaction which is formally the reversal of a $\mathrm{NADP}^{+}$-dependent dehydrogenation of myo-inositol to 2-keto-myo-inositol. This enzyme, which will be referred to as ketoinositol 
Table 2. Ketoinositol reductase and ketoinositol dehydratase activities in wild-type Salmonella, mutant $I$, mutant $D$ and recombinants

Salts medium supplemented with succinate $(0.2 \%)$ and inositol $(0.2 \%)$ was inoculated with a culture of the desired strain grown on salts medium containing succinate. The cultures were grown with shaking at $37 \mathrm{C}$ until the extinction at $620 \mathrm{~nm}$ was approximately $\mathrm{I}$. Organisms were harvested, extracts prepared and enzymes assayed as described in the text.

Sp. act. (units/mg protein)

$\begin{array}{lcc}\text { Strain } & \begin{array}{c}\text { Ketoinositol } \\ \text { reductase }\end{array} & \begin{array}{c}\text { Ketoinositol } \\ \text { dehydratase }\end{array} \\ \text { Wild-type } & 28.4 & 115 \cdot 0 \\ \text { Mutant D } & 115.0 & 369 \cdot 0 \\ \text { Mutant I } & 0.8 & 1.9 \\ \text { Recombinant } 1^{*} & 64.8 & 208 \cdot 0 \\ \text { Recombinant } 2^{*} & 72.4 & 221 \cdot 0 \\ \text { Recombinant } 3^{*} & 49 \cdot 2 & 159 \cdot 0\end{array}$

* From transduction with phage grown on the wild-type strain as donor.

Table 3. Ketoinositol reductase activity in organisms grown from different inocula on citrate and inositol

Wild-type Salmonella typhimurium was grown as described in Table 2 with the growth substrates and inocula indicated. Ketoinositol reductase was assayed as described in the text. The contribution made by the inositol-grown inoculum to the enzyme specific activity of the citrate + inositol culture was estimated to be $7 \cdot 7$ units $/ \mathrm{mg}$ protein.

\begin{tabular}{|c|c|c|c|c|}
\hline \multirow[b]{2}{*}{ Growth substrate } & \multirow{2}{*}{$\begin{array}{l}\text { Growth substrate } \\
\text { for inoculum } \\
\text { culture }\end{array}$} & \multicolumn{2}{|c|}{$\begin{array}{c}\text { Extinction of culture } \\
\text { at } 620 \mathrm{~nm}\end{array}$} & \multirow{2}{*}{$\begin{array}{l}\text { Ketoinositol } \\
\text { reductase } \\
\text { sp, act. (units! } \\
\text { mg protein) }\end{array}$} \\
\hline & & At start & At end & \\
\hline Citrate + inositol & Citrate & 0.06 & $1 \cdot 05$ & $\mathrm{I} \cdot 2$ \\
\hline Citrate + inositol & Inositol & 0.06 & 1.09 & $57 \cdot 8$ \\
\hline Inositol & Inositol & 0.06 & 0.91 & 140.0 \\
\hline
\end{tabular}

reductase, was inducible by myo-inositol. When a preparation of ketoinositol reductase, obtained by protamine sulphate and ammonium sulphate fractionation of the crude extract and heat-treated to inactivate ketoinositol dehydratase, was incubated with ketoinositol and NADPH, a substance accumulated which caused the reduction of $\mathrm{NAD}^{+}$in the presence of an extract of inositol-grown cells of $A$. aerogenes and was presumably myo-inositol. Furthermore, an extract of inositol-grown $S$. typhimurium catalysed the breakdown of inositol, as judged by the assay of this cyclitol by the enzymatic method, and the concomitant accumulation of strongly reducing product(s). As shown in Table I, the formation of this reducing compound was greatly enhanced by the provision of $\mathrm{NADP}^{+}$, but not of $\mathrm{NAD}^{+}$. These findings support the proposed involvement of a NADP+-linked dehydrogenation of myo-inositol, though the identity of the reducing material is at present unknown.

Inositol-negative mutant and inositol-positive recombinants produced by $P_{22}$ transduction. A mutant incapable of utilizing myo-inositol as growth substrate was isolated as follows. Wild-type Salmonella typhimurium, when spread on Levine eosin methylene-blue agar (Difco) medium supplemented with $\mathrm{I} \%$ (w/v) myo-inositol, yielded colonies with light pink centres. After mutagenization of the wild-type strain with ethyl methane sulphonate, an isolate was obtained which on the same medium yielded colonies with dark centres. This mutant, designated $\mathrm{D}$, proved capable of forming significantly higher levels of ketoinositol reductase 


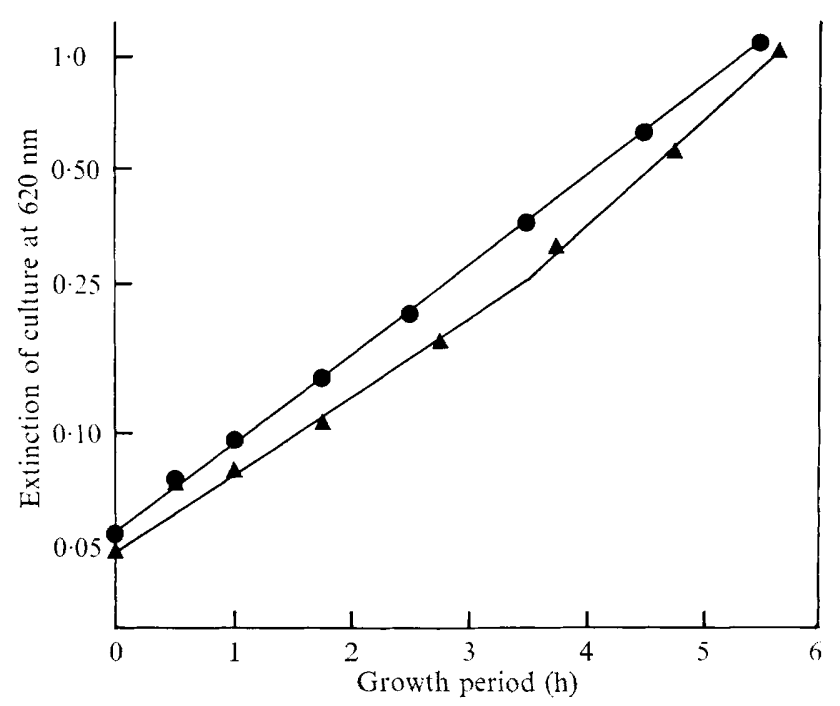

Fig. 2. Growth of Salmonella typhimurium on citrate +inositol medium from citrate-grown and inositol-grown inocula. Cultures CI-C (O) (from citrate-grown inoculum) and $(\boldsymbol{\Delta})$ CI-I (from inositol-grown inoculum) were prepared and incubated as described in Fig. 3. Growth was monitored by measuring extinction of the cultures at $620 \mathrm{~nm}$.

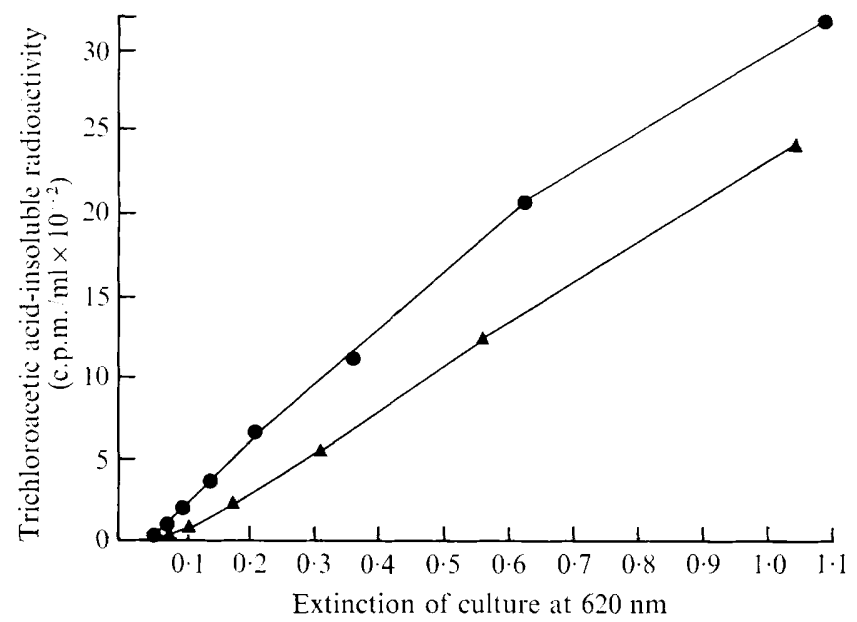

Fig. 3. Incorporation of radioactivity from $\left[\mathrm{I}, 5^{-14} \mathrm{C}\right]$ citrate into Salmonella typhimurium growing on citrate + inositol from citrate-grown and inositol-grown inocula. Cultures CI-C and CI-I contained salts medium $(30 \mathrm{ml})$ with $\left[1,5^{-14} \mathrm{C}\right]$ citrate $(0.2 \%, 2.5 \mu \mathrm{Ci})$ and myo-inositol $(0.2 \%)$. Culture $\mathrm{CI}-\mathrm{C}$ was inoculated with organisms from a logarithmic phase culture grown with citrate as carbon source and culture CI-I was inoculated with organisms from a similar culture grown on inositol. The two cultures were incubated with shaking at $37^{\circ} \mathrm{C}$. Samples were withdrawn at appropriate times for measurement of growth (extinction at $620 \mathrm{~nm}$ ) and of trichloroacetic acid-precipitable radioactivity. Culture CI-C (๑); culture CI-I ( $\mathbf{\Delta})$. 


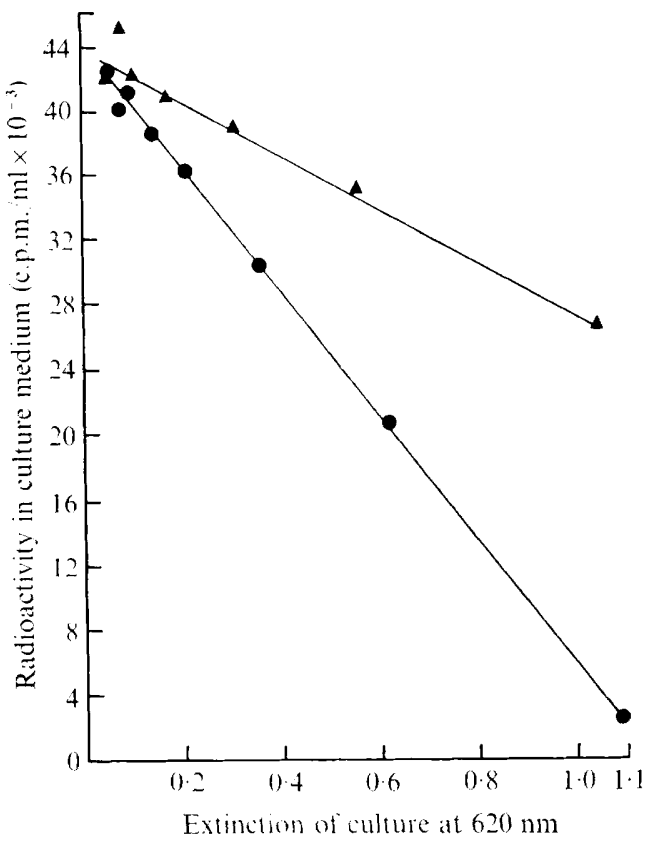

Fig. 4. Residual radioactivity in the media of cultures CI-C and CI-I. Samples of cultures CI-C and CI-I (see Fig. 3) were assayed as described in the text. Culture CI-C ( $\bullet$ ); culture CI-I ( $\Delta)$.

and of ketoinositol dehydratase than the wild-type strain when grown in salts medium containing succinate and inositol (Table 2) or citrate and inositol. Mutant D was further mutagenized with $N$-methyl- $N^{\prime}$-nitro- $N$-nitrosoguanidine and a second isolate, mutant I, was obtained which produced completely white colonies on eosin methylene-blue agar plates containing inositol. Mutant I was incapable of utilizing myo-inositol for growth, and relative to the wild-type and mutant $\mathrm{D}$ produced greatly reduced levels of ketoinositol reductase and of ketoinositol dehydratase (Table 2), when grown in medium containing succinate and inositol. Transduction of mutant I with the temperate phage P22 grown on the wild-type strain generated recombinants that utilized inositol for growth. Controls in the transduction experiment did not show any significant spontaneous reversion of mutant I or recombination due to unequal crossing-over. Inositol-positive recombinants were also obtained when mutant I was transduced with phage grown on isolate D. A few of the transductants, after being purified by restreaking, were analysed for their ability to synthesize ketoinositol reductase and ketoinositol dehydratase. The results, presented in Table 2, show clearly that the abolition of the lesion which prevented growth on inositol also restored the capacity to synthesize the two enzymes. This genetic evidence suggests, as does the biochemical evidence presented above, that these two enzymes are associated with inositol degradation in S. typhimurium. The pattern of enzyme synthesis in mutant I, mutant D and the recombinants points to the possibility that the enzymes of the inositol catabolic pathway are subject to a common genetic control in Salmonella as in Aerobacter (Sundaram, 1972).

Repression of ketoinositol reductase by citrate. Like many inducible enzymes, ketoinositol reductase is sensitive to catabolite repression. Thus the level of the enzyme in cells grown in media containing inositol and either glucose or citrate was low relative to the level in cells grown on inositol alone. However, the enzyme level in cells grown in a medium that 


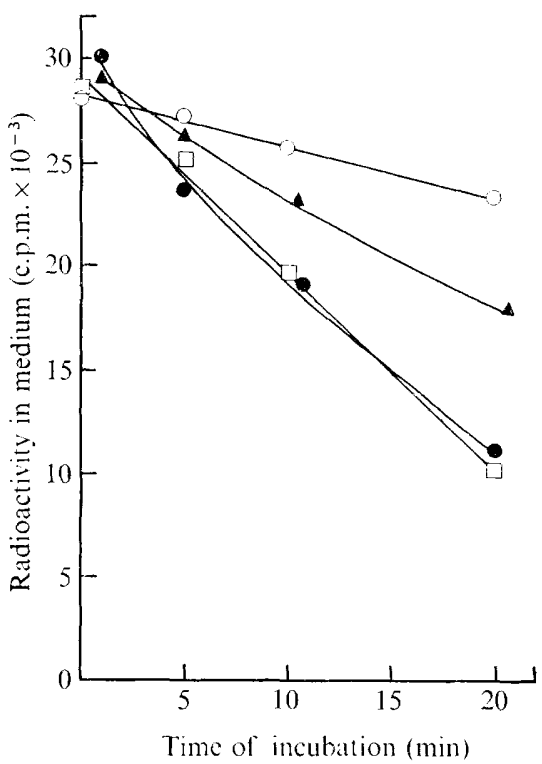

Fig. 5. Metabolism of $\left[1,5^{-14} \mathrm{C}\right]$ citrate by non-growing organisms. Cultures CI-C and CI-I were prepared essentially as described under Fig. 3 but with non-radioactive citrate. Two other cultures, C with citrate as carbon source and I with inositol as carbon source, were also prepared using citrategrown and inositol-grown cells respectively as inoculum. All four cultures were allowed to attain an extinction at $620 \mathrm{~nm}$ of approximately 0.5 ; this represented a nearly tenfold increase in cell mass. Cell suspensions having approximately the same extinction at $620 \mathrm{~nm}$ as the cultures were prepared, and incubated with $\left[1,5^{1+} \mathrm{C}\right]$ citrate in the presence of chloramphenicol to prevent growth and protein synthesis as described in the text; the radioactivity remaining in the media was determined at appropriate times. The radioactivity values given are for the entire $(5.5 \mathrm{ml})$ reaction mixtures, and for the cell suspensions have all been normalized to an extinction of 0.5 (at $620 \mathrm{~nm}$ ) using the experimentally determined extinction values. Organisms from culture $\mathbf{C}(\square)$; organisms from culture I (O); organisms from culture CI-C (๑); organisms from culture CI-I ( $\mathbf{A})$.

contained both citrate and inositol varied depending on the growth history of the culture used as inoculum. When cells that had been growing exponentially on citrate were the inoculum, virtually no ketoinositol reductase was synthesized on citrate plus inositol. By contrast, when an exponentially growing culture on inositol was used as inoculum, the specific activity of the enzyme, even after more than four doublings of the cell mass on citrate plus inositol, was nearly $36 \%$ of the specific activity seen in organisms fully induced with inositol (Table 3).

Citrate utilization and metabolism. In order to determine whether this difference in enzymatic constitution was reflected in the pattern of substrate utilization, the fate of $\left[1,5^{14} \mathrm{C}\right]$ citrate, supplied with inositol in the medium, was studied during growth initiated by the two different inocula. Fig. 2 records the course of growth of the two cultures. Culture CI-C, which was inoculated with citrate-grown cells, maintained an almost constant growth rate throughout the experimental period. On the other hand, culture CI-I, which received an inoculum of inositol-grown organisms, showed a distinct acceleration of growth in the later stages of the experiment. The incorporation of radioactivity from $\left[\mathrm{I}, 5^{-14} \mathrm{C}\right]$ citrate into trichloroacetic acid-precipitable material was significantly less in the case of culture CI-I than in culture CI-C (Fig. 3). Thus, when the extinction of the cultures was 0.5 , representing an approximately tenfold increase in cell mass, the radioactivity in CI-I organisms was 
about $64 \%$ of the radioactivity in CI-C organisms, and at an extinction of $\mathrm{I}$, representing a 20 -fold increase in cell mass, this figure was $76 \%$. The overall utilization of citrate per unit mass of cells produced, which can be roughly estimated from the data of Fig. 4 showing the radioactivity remaining in the medium at various stages of growth, was for culture CI-I only about $38 \%$ of that for culture CI-C when the cell mass had multiplied ten times; this figure was $4 \mathrm{I} \%$ when the cell mass had increased 20 -fold. An exact quantitative evaluation of citrate utilization in the two cultures is precluded by the fact that the radioactive citrate used in the experiment was not uniformly labelled with ${ }^{14} \mathrm{C}$.

It is apparent from these results that in culture CI-C essential enzymes of inositol catabolism were almost completely repressed and that the organism almost exclusively utilized citrate for growth. By contrast, culture CI-I continued to make the inositol enzymes at an appreciable rate and utilized both inositol and citrate; the lack of constancy in the growth rate (Fig. 2) is consistent with this conclusion and also suggests a shift in the relative proportions of the two substrates utilized. The degradation of non-radioactive inositol in culture CI-I would a priori reduce the utilization of radioactive carbon from "citrate by contributing unlabelled metabolites. An additional possibility is that the potential of organisms in culture CI-I to metabolize citrate might be lower than that of those in culture CI-C. The data recorded in Fig. 5 lend some support to this idea. They show that organisms of culture $\mathrm{CI}-\mathrm{C}$ and organisms grown on citrate remove $\left[\mathrm{I}, 5^{-14} \mathrm{C}\right]$ citrate from the medium at similar rates under non-growing conditions. By contrast organisms of culture CI-I metabolized the citrate at a significantly lower rate; the rate of metabolism by inositol-grown organisms was even slower.

\section{DISCUSSION}

Although it has not been possible to demonstrate in vitro a dehydrogenation of myoinositol in the Salmonella system in terms of a reduction of $\mathrm{NADP}^{+}$, various lines of evidence, both biochemical and genetic, indicate that inositol catabolism in this organism proceeds by a route similar to that demonstrated in Aerobacter aerogenes, and that the two enzymes, ketoinositol reductase and ketoinositol dehydratase, are involved in this process.

A more interesting result of this study is that the extent of repression by citrate of the inositol-catabolizing enzyme system (represented in these experiments by ketoinositol reductase) can vary with the growth history of the inoculum. Under most conditions the organism prefers citrate to inositol as growth substrate. This might be expected from the somewhat faster rate of growth on citrate (mass doubling time $=77 \mathrm{~min}$ ) than on inositol (mass doubling time $=84 \mathrm{~min}$ ) and the inducible nature of the inositol-degrading system; such a system would be repressed in the presence of a substrate capable of supporting a faster rate of growth (Stanier, Doudoroff \& Adelberg, 1970). The preference for citrate over inositol was indicated by the fact that in culture CI-C the inositol-catabolizing enzyme system was virtually completely repressed and that even in culture CI-I this enzyme system was partially repressed and the organisms contained the machinery to metabolize citrate (Fig. 5) and utilized citrate for growth. However, provided the organisms are given a head start in inositol catabolism, as in culture CI-I, they can continue to produce the inositol enzyme system and to utilize this cyclitol for growth even in the presence of citrate. The head start in this experiment was provided by ensuring that the inositol-grown organisms used to start the CI-I culture were still in the exponential growth phase so that there was virtually no lag before culture CI-I started growing (Fig. 2). This was an important condition, for if cells of the inositol culture were allowed to stay in the stationary phase for an appreciable period and only then used as inoculum, there was usually a significant lag before exponential growth 
ensued in culture CI-I and ketoinositol reductase was much more strongly repressed than is shown in Table 3 .

Fig. 5 shows clearly that one or more enzymes of the citrate-metabolizing system are inducible by citrate. Although the present study does not identify which of the enzymes is inducible, the demonstration that the citrate transport system, and possibly other enzymes, are inducible in Aerobacter aerogenes (Davis, 1956; Wilkerson \& Eagon, I972) suggests that a similar situation obtains in Salmonella typhimurium. This property of the citrate system presumably explains why cells of culture CI-I, in an actively growing state and already endowed with the inositol-catabolizing system, can continue to synthesize and use this system to the relative exclusion of the citrate system. The rather small difference between the growth rates on citrate and on inositol, which implies that citrate is only marginally superior to inositol in supporting growth, may also be a relevant factor. It is noteworthy in this context that organisms of culture CI-I, even after increasing their mass nearly ten times, are not fully induced for the citrate-metabolizing system (Fig. 5).

In a discussion of how control mechanisms discovered in micro-organisms might be relevant to the problem of cellular differentiation, Monod \& Jacob (196I) proposed a number of theoretical model systems. In one of these models, they suggested that in a system where two metabolic pathways are possible, one pathway, provided it once had a head start or a temporary metabolic advantage, will permanently inhibit the other. In the Salmonella typhimurium system, the present study demonstrates a somewhat analogous situation: the inositol enzyme system, which normally is repressed when citrate is available, can under certain special conditions be synthesized and enable inositol to be utilized for growth even when citrate is present in the medium. A similar variation in phenotype, not dictated by an alteration of genotype or of immediate environmental conditions, has been demonstrated in the $\beta$-galactosidase system of Escherichia coli (Cohn, I956). Cohn observed that $\beta$-galactosidase, which is severely repressible by glucose, would be synthesized at a relatively high level even in the presence of glucose if the cells were preinduced with methyl- $\beta$-D-thiogalactoside prior to the addition of glucose.

This investigation was carried out in the Department of Biology, Massachusetts Institute of Technology, Cambridge, Massachusetts, U.S.A. I thank Professor Boris Magasanik for financial support, advice and stimulating discussions, Dr Thomas Berman for assistance in the preparation of 2-keto-myo-inositol, Dr Paul Margolin for providing the Salmonella typhimurium LT2 culture, the U.S. Educational Foundation in India for the award of a Fulbright travel grant, and Miss Susan N. Dilks for preparing the Figures.

\section{REFERENCES}

Anderson, W. A. \& Magasanik, B. (I971 $a$ ). The pathway of myo-inositol degradation in Aerobacter aerogenes. Identification of the intermediate, 2-deoxy-5-keto-D-gluconic acid. Journal of Biological Chemistry 246, 5653-566I.

Anderson, W. A. \& Magasanik, B. (I97I $b$ ). The pathway of myo-inositol degradation in Aerobacter aerogenes. Conversion of 2-deoxy-5-keto-D-gluconic acid to glycolytic intermediates. Journal of Biological Chemistry 246, 5662-5675.

Berman, T. \& Magasanik, B. (I966a). The pathway of myo-inositol degradation in Aerobacter aerogenes. Dehydrogenation and dehydration. Journal of Biological Chemistry 24I, 800-806.

Berman, T. \& Magasanik, B. (1966 b). The pathway of myo-inositol degradation in Aerobacter aerogenes. Ring scission. Journal of Biological Chemistry 24r, 807-81 3.

Charalampous, F. C. (1959). Biochemical studies on inositol. V. Purification and properties of the enzyme that cleaves inositol to D-glucuronic acid. Journal of Biological Chemistry 234, 220-227. 
CoHN, M. (1956). On the inhibition by glucose of the induced synthesis of $\beta$-galactosidase in Escherichia coli. In Enzymes: Units of Biological Structure and Function, pp. 4I-46. Edited by O. H. Gaebler. New York: Academic Press.

Davis, B. D. (1956). Relations between enzymes and permeability (membrane transport) in bacteria. In Enzymes: Units of Biological Structure and Function, pp. 509-522. Edited by O. H. Gaebler. New York: Academic Press.

Hershey, A. D. \& Chase, M. (1952). Independent functions of viral protein and nucleic acid in growth of bacteriophage. Journal of General Physiology 36, 39-56.

Loewus, F. A., Kelley, S. \& Neufeld, E. F. (1962). Metabolism of myo-inositol in plants: conversion to pectin, hemicellulose, D-xylose and sugar acids. Proceedings of the National Academy of Sciences of the United States of America 48, 421-425.

Lowry, O. H., Rosebrough, N. J., Farr, A. L. \& Randall, R. J. (I95I). Protein measurement with the Folin phenol reagent. Journal of Biological Chemistry 193, 265-275.

Margolin, P. (1963). Genetic fine structure of the leucine operon in Salmonella. Genetics 48, 44 I-457.

MONOD, J. \& JACOB, F. (I961). General conclusions: teleonomic mechanisms in cellular metabolism, growth and differentiation. Cold Spring Harbor Symposia on Quantitative Biology 26, 389-40I.

Posternak, T. (1952). Biochemical Preparations 2, pp. 57-64. New York: J. Wiley.

Sivak, A. \& Hoffman-Ostenhof, O. (196I). Enzymes of meso-inositol catabolism in the yeast, Schwanniomyces occidentalis. Biochimica et biophysica acta 53, 426-428.

Stanier, R. Y., Doudoroff, M. \& Adelberg, E. A. (1970). General Microbiology, p. 285. London: Macmillan.

Sundaram, T. K. (1972). Regulation of myo-inositol catabolism in Aerobacter aerogenes. Journal of Bacteriology (in the Press).

Umbreit, W. W., Burris, R. H. \& Stauffer, J. F. (1964). Manometric Techniques. Minneapolis, Minnesota: Burgess Publishing Co.

Weissbach, A. (1958). Enzymic determination of myo-inositol. Biochimica et biophysica acta 27, 608-6ri I.

WiLKeRSON, L. S. \& EAGON, R. G. (1972). Transport of citric acid by Aerobacter aerogenes. Archives of Biochemistry and Biophysics 149, 209-22 I. 